\title{
A Study of ESP English Writing Based on Mobile Internet
}

\author{
Huang Baomei, Wan Liang \\ Guangxi Vocational \& Technical College, \\ Mingyang Industrial Area, Nanning, Guangxi, China 530226
}

\begin{abstract}
The thesis takes Writing an English Resume as an example. It conducts on analyzing the learning situation of student, genre analysis and then carry out the ESP English writing teaching based on mobile Internet. The author advocates the use of an autonomous learning approach in the following three stages: pre-class stage, while-class stage, and post-class stage. It runs through prewriting, writing, modification and rewriting. The result shows that the ESP English writing teaching based on mobile Internet is beneficial to improve the writing quality and independent learning ability of English learners, improving the teaching effect and enhancing the competitiveness of students' future career.
\end{abstract}

Keywords-Mobile Internet; English of higher vocational; ESP writing teaching;Teaching innovation

\section{INTRODUCTION}

Writing is a test of language output ability. Writing ability is an important embodiment of English application ability. From 2015 to 2017, millions of the same composition was sponsored by National Association of English Writing. The number of students participating in National Higher Vocational College from 2015 to 2017 was 109,000, 123,000 and 98,000 respectively. This indicates that the use of mobile Internet to write has been implemented in a number of schools and has been recognized by quite a number of higher vocational students.

\section{LITERATURE REVIEW}

Many scholars in China have done a lot of teaching and research on the Internet teaching of English writing. Tian Hailong (2001) [1] proposes using computer and network to improve students' writing ability. And he believes that there are two advantages for computer aided English writing teaching. Students are more likely to engage in writing, and it is easier for teachers to explain the writing process. The research by Zhang Hongxia, Wang Tongshun (2004) [2] shows that the online writing process is complete and detailed, and the evaluation of the model can be used to assess the process of the process. Yong-lin Yang (2004)[3] puts forward a training system based on the concept of digital learning writing, Tsinghua University in 800,000 - word English writing corpus based on constructed a relatively perfect writing training platform. Zhang Yanhong (2008) [4] conducts a dynamic evaluation of college English online teaching. Her research shows that network teaching is beneficial to exert students' subjective initiative and the improvement of students' writing level.And at the same time it can be able to reflect the guidance of teachers. Jiang Ping (2016) [5] points out that mobile Internet technology has an obvious promotion effect on the improvement of English writing ability of higher vocational students. In the 19th National Congress of the Communist Party of China, President Xi (2017) [6] proposes strengthening the network education, pushing the Internet, big data, artificial intelligence and real economy deep integration.

After the 1980s, with the popularization of discourse analysis and genre analysis, ESP teaching entered a new stage. The objective of genre analysis is to promote ESP teaching. Davies (1988) [7] writes an outline based on the genre to enable students to identify and analyze a variety of genres to read or write in their course study. Swales (1990) [8] puts forward a number of "genre writing" class activities and practice forms. Flowerdew (1993) [9] combines genre teaching and process teaching methods to teach students to write various genres. Swales is the pioneer of the academic language, while Bhatia has extended the corpus on the basis of Swales theory into ESP fields, such as legal English and business English. Hutchinson and Waters regards ESP as an approach. Pauline c. Robinson reveals that "goal-oriented" and "need analysis" are the most basic criteria for ESP teaching. (Dudley-Evans \& St. John, 1998) [10]. In the content of ESP teaching, students should be fully utilized to stimulate and establish a professional field to study styles and skills.

Qin xiubai (2003) [11] uses student-centered, authenticity and needs analysis as ESP's three teaching principles. He also points out that "ESP is a teaching method, a teaching policy or teaching concept. Only courses in ESP teaching approach are truly ESP courses. Wen Qiufang's $(2013,2014)$ [12] outputdriving input-enabled hypothesis is catering specially for advanced learners and promise to be a forceful theory influencing the reform of College English education, especially the reform and practice of ESP in China. Cai Jigang (2016) [13] clearly puts forward college English is a tool for college students, which is professional learning service target. We implement academic English to the core of college English curriculum system. College English can meet demand of national and professional rather than individual development needs. Huang Ping, Tan Tianzhi, Xie Shu-ying (2017)[14]the focus of foreign ESP analysis is EAP (academic English analysis), while the domestic ESP analysis is EOP (professional English) analysis . In particular, vocational 
training is the main purpose of higher vocational college. Deng Liming (2017) [15] puts out that the development of the learners' corpus ability directly influences the improvement of their professional discourse ability, and the learners' ability to acquire specialized knowledge skills will depend greatly on the development of their language ability. But higher professional education in domestic, ESP teaching mode is applied to the teaching of English writing in mobile Internet and the empirical research and practice are few.

The author carried out the relevant empirical research in the teaching of English writing in Guangxi Vocational \& Technical College from 2015 to 2017. This paper is an example of the design and practice of the writing mode of mobile Internet for the students of Automobile Testing and Maintenance Technology.

\section{THE STUDY}

\section{A. Research questions and Teaching materials}

Is it more conducive to students' professional development to integrate with public English into their majors? Whether mobile Internet can really improve students' writing quality?

Teaching materials is Career Express English Book 3.

\section{B. Teaching objects and teaching aims}

\section{1) Teaching objects}

The teaching objects are the second semester of Grade One for Automobile Testing and Maintenance Technology in Guangxi Vocational \& Technical College in 2016. The students have the following three characteristics: They are exploring career goals through initial contact with professional courses. As digital natives, they are interested in using Internet and mobile phones. They are eager to have the knowledge of skills in writing English resume. But their English foundation is weak and they lack of confidence in the writing English resume which is related to the auto industry.

\section{2) Teaching aims}

According to the teaching content and analysis, we set the teaching objectives as follows: the first one is knowledge objectives. Students can master the high frequency vocabulary of job application, and learn to describe relevant vocabularies and sentences which are close related with Auto job .The second one is skill objectives. Students can use simple English to describe the auto positions and relevant professional courses, and they can master the skills and writing of English resume and write out the first draft then upload to www.pigai.org. The third one is professional skill. Students can write out their own English resume based on their choice of positions and specialties combining with the requirements of vocational positions of car testing and maintenance.

\section{Teaching process}

Writing process is a very complex mental cognitive process and creation process. So far, linguistics specific description of the writing process has not yet been fully agreed opinion: some think that includes writing process plan, write the first draft, revision three stages. And some proposed into trigger, collect data, written, modify and edit most five stages. But most think that writing process mainly includes five steps: writing preparation, writing first draft, modify, feedback and rewriting. And in my experimental work, it contains Pre-class stage, While-class stage and Post-stage, while it also contains the above five steps.

\section{1) Pre-class stage}

The teacher uses Vocational Educational Cloud Class (zjy2.icve.com.cn) for delivering online learning resources, including audio, video, micro learning resources, PPT and text etc. for students studying before class. And assign students to complete the initial draft of the resume and submit to their account of www.pigai.org. Students use their APP to complete their own study before class anytime and anywhere. After that, combining with personal career goals, the students write personal English resumes on mobile phones and upload to the www.pigai.org. Students will be able to get the initial draft marks and suggestions for correcting the composition immediately. The teacher quickly grasps feedback for all students' learning situation by www.pigai.org, and the average grade of the class was 68.1. There are 3341 errors in all the articles. Errors mainly focus on non-standard sentences (1325), improper use of nouns (678), improper collocation (634) misspellings (543), misuse of words (97), preposition errors (35), Adjective errors (29).

\section{2) While-class stage}

a) The students watch the Job-hunting video. Make sure the students know that an excellent resume will make them shine in a job hunting. But how to write an excellent English resume?

\section{b) Consolidate the vocabulary}

Language input is the forerunner of cultivating students' written communication. According to the student's initial draft data, the teacher uses the mind map to comb the common vocabulary of writing English resume. The teacher combines the wrong case to carry on the explanation. For example, Male sex is used in Male and Female Female, rather than boy and girl. Many of the students on the resume are missing the career objectives. The teacher leads the students to use the Internet, Youdao dictionary to search car professional post information and make word trees. For example, in a $4 \mathrm{~s}$ car shop, there are many positions, such as automobile repairer, car salesman, car doctor, car beautician, Automobile claimants, car pilot, Auto parts collector, car specialist, car after-sales tracker, technical manager, maintenance engineer, automobile inspector, maintenance engineer, automobile engineer automobile inspector, automobile designer, car sales consultant etc. In order to strengthen the memory, the teacher design to guess the word game for the students, which is fun and easy to break car professional vocabulary. 


\section{c) Strengthen the sentence pattern}

The first draft of most student's resume are in Chinglish. Deng Liming (2001) [16] points out that negative transfer of native language in English writing, which seriously hindered the improvement of students' English writing ability. To standardize sentence expression, the author classified the problem cases according to the main points and compared the corresponding common sentence patterns. After the introduction, the students will practice some sentences about job objective, education background, work experience and qualifications. At the same time, we will guide students to search the English expressions of different automobile specialty positions and required quality based on the word tree. Such as for a car repairer who should have strong sense of service and bear hardships. While for a car inspector who should have good ability of analysis and diagnosis for a car. In this way, students are encouraged to participate in vocational training.

\section{d) Modify and present resumes}

After that, students use their mobile phones to modify their resumes and get results. From the data analysis, the average score is up to 77.9. An average of 9.8 points was raised. There are 1382 errors in all the articles. Errors mainly focus on nonstandard sentences (717), improper use of nouns (249), improper collocation (248) misspellings (128), misuse of words (17), preposition errors (7), Adjective errors (3). Which effectively solves the teaching key points and difficult points. The teacher invites students with high scores to present their English resume and consolidate the achievements of exchange learning. Then the students are on peer-correction on the Internet.

\section{e) Tummary of upgrade}

To efficiently solve the problem of layout design, the teacher recommends resume template and design and production website http://www.500d.me for student making their resume perfect, helping students combining with the characteristics of professional positions and personal style, rapidly design resume shine. Finally, the teacher summarized the main points of the resume.

\section{3) Post-class stage}

After class, the students self-study http://www.500d.me and finish their final resume. Students vote for the best resume through zjy2.icve.com.cn

\section{FINDING AND DISCUSSION}

\section{A. Finding}

1) Questionnaires and Data analysis

The future education is Data (Bill Gates).For Question 1, $93 \%$ of students think that combining professional knowledge with writing enhances their motivation and confidence, thus making efforts to learn English better to improve their employment competitiveness. $88 \%$ of students think their writing is more motivated and more expressive. In order to write an English resume that meets the needs of professional talents, $92 \%$ of students express that they would actively learn about writing knowledge and vocabulary related to their major.

For Question 2, 92\% of students say mobile Internet have significantly improved their English writing skills. In particular, professional vocabulary, sentence structure, genre change and analysis ability have been improved greatly. With the help of mobile phone, www.pigai.org., and other information tools and technologies can enhance the students' writing consciousness and improve their English. 83\% of the students say that they make the final draft more than two times. In order to write satisfying works, $95 \%$ of students use mobile Internet to access data and revise to improve their writing level.

\section{2) Learn behavioral data autonomously}

This English resume is written in 217 essays. The students revise compositions with1, 572 times, average revision 7.24 times. About $73 \%$ of the students revised their articles many times. More than $10 \%$ of the students revise their compositions 20 times. Students are generally good at self-study.

\section{3) Fractional change of data}

TABLE I. THE FIRST DRAFT SCORES VS. THE FINAL DRAFT SCORES

\begin{tabular}{|l|l|l|l|l|}
\hline \multirow{2}{*}{ Scores } & \multicolumn{3}{|l|}{ The first draft } & \multicolumn{2}{l|}{ The final draft } \\
\cline { 2 - 5 } & $\begin{array}{l}\text { Number of } \\
\text { students }\end{array}$ & percentage & $\begin{array}{l}\text { Number of } \\
\text { students }\end{array}$ & percentage \\
\hline $\begin{array}{l}\text { More than } \\
90\end{array}$ & 0 & $0 \%$ & 4 & $1.85 \%$ \\
\hline $80-89$ & 20 & $9.22 \%$ & 61 & $28.11 \%$ \\
\hline $70-79$ & 50 & $23.04 \%$ & 98 & $45.16 \%$ \\
\hline $60-69$ & 104 & $47.93 \%$ & 43 & $19.81 \%$ \\
\hline $\begin{array}{l}\text { Less than } \\
60\end{array}$ & 43 & $19.81 \%$ & 11 & $5.07 \%$ \\
\hline
\end{tabular}

From table 1, we can see that, there are four students can get high score. It is rare for students of this major. The number of students from 70 to 89 rose significantly, with the number of students between 60 and 69 falling significantly, and the number of students who failed to fail significantly decreased. This shows that the students gained recognition in their revision and satisfied the sense of achievement. 
4) There is obviously increase in academic vocabulary related to auto maintenance.

TABLE II. THE WORD FREQUENCY OF ACADEMIC VOCABULARY

\begin{tabular}{|l|l|l|l|}
\hline Word & Frequency & Word & Frequency \\
\hline Technical & 120 & Automobile & 86 \\
\hline Technology & 107 & Engineering & 81 \\
\hline Maintenance & 97 & Professional & 74 \\
\hline Inspector & 93 & Industrial & 67 \\
\hline Vehicle & 87 & Qualification & 65 \\
\hline
\end{tabular}

5) The use of word frequency(noun)used in English resume writing. It shows that students can master the basic words with resume.

TABLE III. THE NOUN FREQUENCY OF ENGLISH RESUME

\begin{tabular}{|l|l|l|l|}
\hline Word & Frequency & Word & Frequency \\
\hline Work & 241 & Ability & 132 \\
\hline School & 240 & Experience & 113 \\
\hline Name & 153 & Vocational & 109 \\
\hline Education & 149 & Scholarship & 97 \\
\hline College & 146 & Awards & 87 \\
\hline
\end{tabular}

\section{B. Discussion}

Online training combined with classroom instruction. Online autonomous learning is a kind of independent learning mode, which is based on students and supplemented by network resources for teaching content. Cloud storage and cloud transport enable teachers to store video data in cloud class, QQ, WeChat and other software in advance for students to download and learn, discuss and practice. Students can use all kinds of network methods, collect the writing resources of writing topics, and realize self-learning and online training. All kinds of corpora can also help students to write, and writing in the age of big data can make students' writing process not tedious and no longer have nothing to say. It is full of fun. With this model, students' interest in learning can be greatly stimulated and they are more willing to make positive contributions to teaching interaction. Especially for ESP, which is both professional and practical, it is difficult to meet the students' demand for courses with limited classroom time and knowledge of books. In this case, network based on strong network platform and rich network resources are needed. (Cai Jigang, 2016) [13] Our survey also shows that the tasks and programs that students study are more likely to motivate them to learn.

Using mobile internet, students are not related to time constraints and can make them available to "anytime, anywhere". So they can use time effectively. Huang Baomei (2017) [17] Mobile learners enjoy "zero limit" learning of any time, any place, anyone and anyway. Mobile technologies simultaneously and interactively support different learning styles. Lacking of authentic foreign language environment and limited time for a Vocational College, the students use mobile internet technology to optimize their learning process. It can significantly decrease the errors of the students' spelling, grammar, and sentences. When they edit the word or sentences, they can correct the mistakes timely. They can get the score and feedback immediately. If they are not satisfied with the scores, they can search the materials and revise them many times until they get the good result, which significantly improve students' motivation, which is a proof of the effective of mobile-internet writing. www.pigai.org automatically records the modification of track and students can feel their progress in writing process, which can eliminate the anxiety of the students' writing process and the disgust of the evaluation feedback. Of course, some studies have found that the scores of intelligent corrections are much higher than those of artificial intelligence, which can't achieve the effect of artificial correction in the coherence of sentences and the beautification of text and language. In combination with teachers' corrections, the teachers' batch correction can make up for the above problems, and use of intelligent correction can make up for the defects in the manual correction validity. Meanwhile the teacher will get the students' results in one second, which help teacher adjust teaching content and methods quickly and directly, improving the classroom efficiency. (Stapleton et al., 2010) [18] such as Beijing word network technology co., LTD. (http://www.pigai.org), can provide real-time online feedback for students' compositions, such as vocabulary, grammar and text. This information can help students in the process of writing word line, and solve the problem of most grammar. So it can improve students' ability of language use, save the teacher time dealing with students' language errors.

\section{CONCLUSION}

The close integration of public English and specialty deepens the innovation and practice of public English teaching reform. The mobile learning is optimized for teaching, strengthening the interaction between teachers and students, improving classroom participation. The large data analysis of www.pigai.org makes the teaching feedback timely and objective. It solves the problem that the teachers could not timely change the opinions of the whole class, which greatly improved the efficiency of the classroom. Information tools and resources are beneficial for learning. They can improve students' self-learning ability and information processing ability. Mobile learning tools allow students to train a foreign language in classroom and extracurricular as well as at any time convenient for them, at a reasonable pace for each student. But the problems associated with rising levels of students' writing through mobile learning not limited to this study. More researches are also needed to intensify the learning process for improving writing in higher vocational college. And more ESP empirical researches are needed to verify the practice and exploration of public English and professional deepen integration to serve the students' career. So that it can promote the reform of English teaching in higher vocational colleges.

We use tasks-driven methods for students to learn while practicing. The application of information technology and the evaluation of diversity stimulate students' interest in learning. Let the students learn happily and be proud for their sense of achievement. The empirical study and application of ESP 
English writing has been popularized from a small number of experimental classes to other departments of our college. So far, there are at least 3,000 students have been benefited. The development of information technology has given higher vocational education teaching new vitality and greatly enriched teaching methods. It has greatly enriched the teaching means, effectively solved the key points and difficulties in the teaching of English resume writing, and improved the students' interest in learning and finally achieved the desired effect.

\section{ACKNOWLEDGMENT}

The research is funded by Advisory Committee of Foreign Language Teaching in Vocational Education, Ministry of Education, RPC, in 2015.(Title: An Empirical Study on the Teaching of English Process Writing in Higher Vocational Colleges Based on Big Data.), Grant No. GZGZ5414-54.

Author brief: Huang Baomei (1976-), Female, Guangxi Zhuang Autonomous Region in CHINA, Lecture of English, Guangxi Vocational \& Technical College, main research interests: Mobile Learning \& Writing and ESP(English for Specific Purposes).

E-mail address: $361690991 @ q q . c o m$

Mobile phone: 13737088634 Post code: 530226

\section{REFERENCES}

1] Tian Hailong.2001, Computer Aided English Writing Instruction Activities and Advantages. [J]Media in Foreign Language Instruction 3 , $11-14$

[2] Zhang Hongxia, Wang Tongshun 2004, E-portfolio - A New Theory and Method for Foreign Language Writing Assessment [J] Media in Foreign Language Instruction 2, 41-44.

[3] Yong-lin, Yang,2004, A Holistic Training System for Writing Based on the Idea o Digitalized [J] Media in Foreign Language Instruction 8,4-11.

[4] Zhang Yanhong,2008, Studying the Dynamic Assessment Mode for Online EFL Writing Teaching[J] Foreign Language World 4,73-81.

[5] Jiang Ping. (2017), The Influence of Mobile Internet Technology on English Writing of Higher Vocational Students. [J] Heihe Education 6 , 37-38.

[6] The reports of the 19th National Congress of the Communist Party of China, 2017.

[7] Davies, F,1998“Designing a writing syllabus in English for Academic purposes: process and product". In P.C. Robinson (ed.): Academic Writing: Process and Product. ELT Documents 129.

[8] Swales, J.1990.Genre Analysis. Cambridge: Cambridge University Press.

[9] Flowerdew,J.1993."An education ,or process, approach to the teaching of professional genres” ELF Journal 47/4.

[10] Dudley-Evans, T \& St John, M.J. 1998. Developments in English for specific purpose: A Multidisciplinary Approach [M].Cambridge: Cambridge University Press.

[11] Qin Xiubai. (2003), The nature, scope and teaching principles of ESP [J] Journal of South China University of Technology (social Science Edition) 4, 79-83.

[12] Wen , Qiufang (2014). On the output-driven input - enabled hypothesis and the reform of college English teaching. A Keynote speech on National Conference of College English Teaching Development, 22-23 March, 2014.

[13] Cai Jigang.(2016) Theoretical Foundations of EAP as an Independen Course in Chinese Tertiary Education.[J] Technology Enhanced Foreign Language Education (TEFLE), 2, 9-16.

[14] Huang Ping, Tan tianzhi2017.A Review on Similarities and Differences between ESP Research in China and Overseas from Synchronic and Diachronic Perspectives[J]Chinese Journal of ESP 1, 1-11.

[15] Deng Liming, Chen, Qiujing. (2017). A study on the development of Chinese students' stylistic competence. 1-3 [M] Beijing: Higher Education Press.

[16] Deng Liming. (2001), Focus on the input of recitation, getting rid of the negative transfer in English writing [J] Foreign Language Education 4 $42-44$

[17] Huang Baomei, (2017), Research on Mobile Learning in Macro Education Reform [J]. China Adult Education 4, 12-14.

[18] .Stapleton, P. \& Radia, P. (2010). Tech-Era L2 Writing:Towards a New Kind of Process[J].ELT Journal, 64 (2):175-183. 